\title{
Current Concepts: Mouse Models of Sjögren's Syndrome
}

\author{
Tegan N. Lavoie, ${ }^{1}$ Byung Ha Lee, ${ }^{1}$ and Cuong Q. Nguyen ${ }^{1,2,3,4}$ \\ ${ }^{1}$ Department of Oral Biology, College of Dentistry, University of Florida, P.O. Box 100424, 1600 SW Archer Road, \\ Gainesville, FL 32610, USA \\ ${ }^{2}$ Center for Orphan Autoimmune Disorders, College of Dentistry, University of Florida, P.O. Box 100424, 1600 SW Archer Road, \\ Gainesville, FL 32610, USA \\ ${ }^{3}$ Eli and Edythe L. Broad Institute, 7 Cambridge Center, Cambridge, MA 02142, USA \\ ${ }^{4}$ Department of Chemical Engineering, Massachusetts Institute of Technology, 77 Massachusetts Avenue, E25-545, \\ Cambridge, MA 02139, USA
}

Correspondence should be addressed to Cuong Q. Nguyen, nguyen@pathology.ufl.edu

Received 16 September 2010; Accepted 10 November 2010

Academic Editor: Andrea Vecchione

Copyright ( $) 2011$ Tegan N. Lavoie et al. This is an open access article distributed under the Creative Commons Attribution License, which permits unrestricted use, distribution, and reproduction in any medium, provided the original work is properly cited.

\begin{abstract}
Sjögren's syndrome $(\mathrm{SjS})$ is a complex chronic autoimmune disease of unknown etiology which primarily targets the exocrine glands, resulting in eventual loss of secretory function. The disease can present as either primary SjS or secondary SjS, the latter of which occurs concomitantly with another autoimmune disease such as rheumatoid arthritis, systemic lupus erythematosus, scleroderma, or primary biliary cirrhosis. Current advancements in therapeutic prevention and treatment for SjS are impeded by lack of understanding in the pathophysiological and clinical progression of the disease. Development of appropriate mouse models for both primary and secondary SjS is needed in order to advance knowledge of this disease. This paper details important features, advantages, and pitfalls of current animal models of SjS, including spontaneous, transgenic, knockout, immunization, and transplantation chimera mouse models, and emphasizes the need for a better model in representing the human SjS phenotype.
\end{abstract}

\section{Introduction}

Sjögren's syndrome (SjS) is a systemic chronic autoimmune disease that targets the exocrine glands, predominantly the salivary glands and lacrimal glands, resulting in xerostomia (dry mouth) and keratoconjunctivitis sicca (dry eyes) [1]. The disease also presents with systemic manifestations involving the destruction of the thyroid gland [2], lungs [3], liver [4], and kidneys [5]. The National Arthritis Data Workgroup using the Olmsted County, MN and 2005 US population prevalence estimates from the Census Bureau has estimated that the prevalence of primary $\mathrm{SjS}(\mathrm{pSjS})$ in the USA approaches 1.3 million with a range of $0.4-3.1$ million of the approximate 214.8 million population, with a female-to-male ratio of about $9: 1$, indicating a probable correlation between disease development and sex hormones [6]. SjS can exist in one of two forms, either primary or secondary [7]. pSjS affects salivary and/or lacrimal glands in the absence of other rheumatic diseases, while its more common secondary form occurs in the presence of other rheumatic diseases, such as systemic lupus erythematosus (SLE) [8], rheumatoid arthritis (RA) [9], scleroderma [10], and primary biliary cirrhosis [11]. The degree of glandular destruction is related to the progressive development of lymphocytic infiltrations which are composed primarily of $\mathrm{CD}^{+}$and $\mathrm{CD} 8^{+} \mathrm{T}$ cells [12], B cells [13], macrophages, and dendritic cells [14].

According to the revised European-American Consensus Group criteria, diagnosis of SjS includes signs of ocular and oral dryness, detection of infiltrating lymphocytes within minor salivary glands with quantification determined by histopathological evaluation, and the presence in serum of autoantibodies, specifically anti-SSA/Ro, anti-SSB/La, and antinuclear antibodies (ANA) [15]. Recently, considerable interest has focused attention on serological evaluations showing the presence of rheumatoid factor (RF), elevated immunoglobulin levels (hypergammaglobulinemia), anti- $\alpha$ fodrin, and the presence of antibodies to the muscarinic acetylcholine receptors, especially the type 3 receptor (M3R) which could impair secretory function [16-24]. 
The precise etiology of SjS remains elusive; however, a number of possible theories have been postulated. Environmental triggers including exposure to Epstein-Barr virus [25], hepatitis C virus [26], and retroviruses including both human T-cell lymphocytic virus type I (HTLV-1) [27] and human endogenous retrovirus (HERV-K113) [28], may initiate epithelial cell activation and a prolonged inflammatory response in genetically predisposed individuals, resulting in systemic autoimmunity. Other hypotheses, including epithelial/acinar cell apoptosis, emergence of autoreactive $\mathrm{T}$ cells, effect of autoantibodies and neurological dysfunction, could consequently contribute to various aspects of SjS pathogenesis [29]. The challenge of attempting to understand the mechanism of human SjS pathogenesis is the inability to learn the biological and immunological occurrence prior to overt clinical signs. End-stage disease is often the only parameter which is used to characterize the entire disease process. As a result, it remains difficult to grasp and understand the disease development. Therefore, animal models for SjS would permit the investigation of the full spectrum of possible etiologies from prior to during and after disease development.

An ideal SjS mouse model should fulfill a range of common characteristics present in human SjS, including etiological, clinical, histological, serological, and immunobiological features as detailed in Table 1. Furthermore, different models will represent SjS in either its primary or secondary form, as demonstrated in Table 2 which clarifies the relevance of each mouse model. This paper will provide a comprehensive examination of many animal models of SjS that mimic fully or various pathological aspects of human SjS.

\section{Spontaneous Mouse Models for Sjögren's Syndrome}

2.1. Nonobese Diabetic Mice. The nonobese diabetic (NOD) inbred strain of mice were developed from a cataract-prone subline (CTS) derived from outbred ICR mice [33]. The NOD strain is not cataract-prone, however, and is most commonly used as a model for human Type 1 insulindependent diabetes mellitus (IDDM or T1D) due to lymphocytic infiltrations (insulitis) which cause the destruction of pancreatic islets. Onset of diabetes in highly inbred NOD mice occurs between 90 and 120 days, with an incidence of $60-80 \%$ in females and $20-30 \%$ in males by 210 days [34]. Spontaneous onset of diabetes in NOD mice presents with hyperglycemia, hypercholesterolemia, glycosuria, ketonuria, polyuria, polydipsia, and polyphagia, all common clinical features of human IDDM. While insulitis develops by 4 weeks (wks) of age, lymphocytic infiltrations in the salivary and lacrimal glands occur at approximately $12-16 \mathrm{wks}$ of age with corresponding loss of secretory function by $20 \mathrm{wks}$ old $[35,36]$. At the onset of SjS-like disease, various signature autoantibodies can also be detected, specifically, antiSSA/Ro, anti-SSB/La and anti-muscarinic receptor type III (M3R) which has been demonstrated to directly contribute to the secretory dysfunction in this animal model and SjS patients.
The NOD mouse model has provided important insight into the genetics of human SjS. The development of T1D in the NOD mouse is controlled by more than 18 chromosomal regions [37]. Early studies involving replacement of individual insulin-dependent diabetes (idd) susceptibility intervals such as $I d d 3, I d d 5, I d d 13, I d d 1$, and $I d d 9$ had minimal effect on the development of autoimmune exocrinopathy or SjSlike disease. Both $I d d 3$ and $I d d 5$ are required for development of salivary and lacrimal dysfunction [38]. When both NOD-derived genetic regions were introduced to the SjS nonsusceptible C57BL/6 strain by crossing C57BL/6.NODc3 mice carrying Idd3 (Autoimmune exocrinopathy 1 (Aec1)) locus and C57BL/6.NODc1t mice carrying Idd5 (Aec2) locus, the C57BL/6.NODc3.NODc1t or C57BL/6.NOD-Aec1Aec2 mouse strain was produced which is homozygous for both Idd3 and Idd5 chromosomal intervals [39]. This double congenic strain fully recapitulated the SjS-like disease process, exhibiting pathophysiological changes at early age, followed by lymphocytic infiltrations of the salivary and lacrimal glands at $12-16 \mathrm{wks}$ of age, then accompanied by the production of autoantibodies to nuclear antigens (SSA/Ro, SSB/La) and M3R in the absence of T1D. The lymphocytic foci (LF) consisted mainly of $\mathrm{CD}^{+}$and $\mathrm{CD} 8^{+}$ $\mathrm{T}$ cells, as well as B lymphocytes with associated loss of saliva production by $20 \mathrm{wks}$ of age. Due to the presence of $\mathrm{T}$ cells and sporadic numbers of dendritic cells and macrophages within infiltrates, an increase in the levels of proinflammatory cytokines such as interleukin-17 (IL-17), IL-22, and IL-23 was also detected locally and systemically. Similar observations are observed in human SjS patients [40].

A recombinant inbred line, known as C57BL/6.NODAec1R1Aec2, was developed to define smaller genetic regions that contain those genes necessary to induce autoimmune exocrinopathy by narrowing the Aec1 region [41]. The genetic region of Aecl locus was shortened from a $48.5 \mathrm{~cm}$ segment to a centromeric piece spanning $19.2 \mathrm{~cm}$. The resultant strain exhibited more rapid SjS-like disease in males, with males developing salivary gland infiltrations at $10 \mathrm{wks}$ of age compared to $19 \mathrm{wks}$ in females. Females presented with more severe sialadenitis and larger infiltrations in the submandibular gland by $22 \mathrm{wks}$; however, they exhibited no dacryoadenitis whereas males exhibited significantly high levels of dacryoadenitis. Furthermore, a homogeneous nuclear ANA pattern was apparent in males as early as 5 wks of age but not until 10 wks in females. Both sexes demonstrated a significant loss of saliva flow rate (35$40 \%$ ) beginning at $5 \mathrm{wks}$ of age, but only males displayed a loss of lacrimal gland secretory function. The lack of lacrimal gland dysfunction in females may be attributed to the loss of a necessary gene on the shortened Aecl locus which could regulate the sex dimorphism presented in SjS.

Interestingly, the major histocompatibility complex (MHC) genes have little or no relation to the development of SjS in the NOD mouse. For example, the MHC class II region, when replaced from $A^{g 7}$ to $A^{b}$ locus in NOD mice, prevented the development of T1D, but the onset of SS-like disease remained unaffected [42]. Also, the NOD.H2 $2^{h 4}$ strain presents with exocrine gland infiltrations and compromised 
TABLE 1: Important criterion for an ideal primary SjS mouse model.

\begin{tabular}{ll}
\hline & Features \\
\hline Etiology & Unknown (possible viral exposure) \\
\hline Clinical & Xerostomia \\
& Keratoconjunctivitis sicca \\
\hline \multirow{3}{*}{ Histological } & Polyclonal lymphocytic infiltrations in the salivary and lacrimal glands \\
& Lymphocytic focus, $>50$ mononuclear cells/mm ${ }^{2}\left(\mathrm{CD} 4^{+}>\mathrm{CD}^{+}\right.$) \\
& Monoclonal B cell proliferation \\
& Progressive destruction of the acinar and ductal cells \\
\hline Serological & Hypergammaglobulinemia \\
& Anti-SSA/Ro and anti-SSB/La autoantibodies \\
& Anti- $\alpha$-fodrin autoantibody \\
& Rheumatoid factor \\
& Antinuclear antibodies \\
& Anti-type 3 acetylcholine muscarinic receptor \\
\hline Additional organ involvement & Heart, blood vessels, lungs, liver, pancreas, stomach, kidneys, bladder, thyroid gland (secondary SjS) \\
\hline \multirow{3}{*}{ Immunobiology } & Diminished apoptosis of lymphocytes \\
& Abnormal MHC expression, H2 ${ }^{+}$-glandular ductal epithelium \\
& Epithelial cell expression of Fas/FasL \\
\hline Other & $9: 1$ female : male ratio \\
& Disease presents in absence of other rheumatic diseases \\
\hline
\end{tabular}

TABLE 2: Primary and secondary SjS mouse models.

\begin{tabular}{|c|c|c|}
\hline Type of SjS & Mouse Model & Secondary to \\
\hline \multirow{10}{*}{ Primary } & Aec1Aec2 & - \\
\hline & NOD.B10-H2 $2^{b}$ & - \\
\hline & NFS/sld & - \\
\hline & IQI/Jic & - \\
\hline & CAII immunization & - \\
\hline & PI3K K.O. & - \\
\hline & ID3 K.O. & - \\
\hline & Ar K.O. & - \\
\hline & Ro immunization & - \\
\hline & Aly/aly & - \\
\hline \multirow{12}{*}{ Secondary } & NOD & Autoimmune diabetes \\
\hline & NOD.H $2^{h 4}$ & Autoimmune thyroiditis \\
\hline & MRL/lpr & RA, SLE \\
\hline & GVHR & SLE \\
\hline & BAFF Tg & SLE \\
\hline & IL-12 Tg & SLE \\
\hline & IL-14 $\alpha \mathrm{Tg}$ & SLE \\
\hline & MCMV & SLE \\
\hline & HTLV-1 tax Tg & RA [30] \\
\hline & TGF- $\beta 1$ K.O. & SLE [31] \\
\hline & IL-6 Tg IL-10 Tg & PBC [32]SLE/Neuropathy \\
\hline & TSP-1 K.O. & IBS \\
\hline
\end{tabular}

K.O.: knockout; Tg: transgenic; SLE: systemic lupus erythematosus; RA: rheumatoid arthritis; PBC: primary biliary cirrhosis; IBS: inflammatory bowel disease.

saliva flow without symptoms of T1D due to the replacement of the $A^{g 7}$ allele with $I-A^{k}$, but continues to develop spontaneous thyroiditis at a low occurrence $(5 \%)[43,44]$.
The NOD.B10-H $2^{b}$ strain also demonstrates an SjS-like phenotype with inflammatory infiltrations in the exocrine glands without the occurrence of T1D due to the replacement of the diabetogenic MHC locus with the MHC locus of C57BL/10 strain that is nonsusceptible to T1D $[45,46]$. As a result, the NOD and NOD-derived animal models have been critical in elucidating the genetic basis of SjS development.

2.2. NZB/W F1 Mice. The first mouse model for spontaneous SjS was the NZB/W F1 hybrid described in 1968 [47]. By crossing the first filial generation New Zealand black (NZB) mouse with the New Zealand white (NZW) mouse, the NZB/W F1 hybrid was produced, which spontaneously developed disease characteristic of SjS and SLE [48]. Mononuclear cell infiltrations were present in both salivary and lacrimal glands by 4 months of age, with more severe lesions in the lacrimal glands of females. Epithelial cell nodules were also present, as well as edematous changes, necrosis, and connective tissue replacement of parenchyma. The primary composition of infiltrations was $\mathrm{T}$ cells with lower numbers of B cells [49]. Hypergammaglobulinemia, pulmonary vasculitis, nuclear autoantibodies, reduced complement levels, and circulating immune complexes were also presented in this mouse model [50].

2.3. MRL/lpr Mice. The MRL/lpr mouse was developed with a genetic mutation of the lymphoproliferation (lpr) gene on chromosome 19 which encodes the structural gene for the Fas antigen [51]. The MRL-lpr/lpr mouse spontaneously develops disease similar to SLE [52] and RA [53], characterized by splenomegaly, arthritis, glomerulonephritis, and massive lymphadenopathy [54]. This model develops an SjSlike phenotype beginning at 2 months of age with the onset of inflammatory infiltrations within the submandibular glands, followed by a less severe inflammation in the parotid and 
sublingual glands. Although an early report suggested that MRL mice do not synthesize anti-SSA/Ro and anti-SSB/La auto-antibodies [55], more recent reports indicate that nearly $30 \%$ of mice develop anti-52 KDa SSA/Ro antibodies, $6 \%$ develop anti-60 KDa SSA/Ro antibodies, and 6\% develop anti-SSB/La antibodies, but not SSA/Ro [56]. Due to the defect in the Fas antigen which controls apoptosis, the $\mathrm{MRL} / \mathrm{lpr}$ mice develop aggressive autoimmune lymphoproliferation contributed by the autoreactive $l p r \mathrm{~T}$ cells which have escaped thymic selection [51].

2.4. NFS/sld Mice. The NFS/sld mouse bears a mutation in the sublingual gland differentiation arrest (sld) gene which affects acinar cell differentiation into mucous-secreting cells in the sublingual gland [57]. At three days of age, the NFS/sld mice are thymectomized without any prior immunization; these mice develop a spontaneous pSjS-like disease [58]. Severe inflammatory infiltrations develop after 4 wks of age in both salivary and lacrimal glands that are composed mainly of $\mathrm{CD}^{+}$and $\mathrm{CD} 4^{+} \mathrm{T}$ cells with a lesser number of $\mathrm{CD}^{+} \mathrm{T}$ cells and $\mathrm{B} 220^{+} \mathrm{B}$ cells. No inflammatory lesions are present in other organs, nor in nonthymectomized mice. Female mice develop a more severe diseased phenotype. NFS/sld mice which developed infiltrations in the glands had significant levels of IgG autoantibodies in sera. The organ-specific 120-kilodalton $\alpha$-fodrin autoantigen which has high sequence homology with the human cytoskeleton protein $\alpha$-fodrin was found within the salivary glands of $\mathrm{NFS} /$ sld mutant mice, indicating a potential role in the development of sialadenitis and dacryoadenitis [59]. The early accumulation of $\alpha$-fodrin within the salivary glands may lead to the observed loss of secretory function by $18 \mathrm{wks}$; however, this is most likely due to aging rather than SjS-like disease phenotype [60].

2.5. IQI/Jic Mice. The IQI/Jic mouse is an inbred strain established from the Imprinting Control Region (ICR) mouse strain similar to NOD. These mice produce antinucleolar autoantibody in response to mercuric chloride exposure [61]. The strain is marked by an increase in the number of B cells within the thymus of aged females, as well as the presence of mononuclear cell infiltrations within the salivary and lacrimal glands. The major composition of inflammatory infiltrations is reportedly $\mathrm{B} 220^{+} \mathrm{B}$ cells, with a lesser numbers of $\mathrm{CD}^{+}{ }^{+} \mathrm{T}$ cells. Concomitantly, acinar cell destruction is observed around large foci. However, small foci consist primarily of $\mathrm{CD}^{+}$cells, indicating that $B$ cells continuously invade the affected organs as the disease progresses. Sialadenitis is present in $80 \%$ of female mice with lesions beginning at 6 months of age, and onethird of the animals produce speckled-type IgG antinuclear autoantibody by 15 months of age. Neither anti-SSA/Ro nor anti-SSB/La autoantibodies were detected. Expression of MHC class II antigen is apparent in the ductal epithelial cells surrounding LF. Additionally, lymphocytic infiltrations are also observed in the pancreas, kidneys, and lungs as the IQI/Jic mice aged [62]. Enhanced expression of kallikrein13 (Klk-13) has been detected in salivary glands, suggesting that Klk-13 may be a candidate autoantigen in SjS that could contribute to the development of sialadenitis due to increased T cell response to organs expressing Klk-13 [63].

2.6. Aly/aly Mice. The aly/aly mouse possesses the homozygous autosomal recessive mutation alymphoplasia (aly) gene, resulting in loss of lymph nodes and Peyer's patches [64]. Subsequently, aly/aly mice readily accept allogenic skin grafts and demonstrate impaired response to $\mathrm{T}$ cell-dependent antigens due to absence of germinal center formation. These mice spontaneously develop an SjS-like phenotype by $14 \mathrm{wks}$ of age, with worsening disease as they aged, presenting with chronic salivary and lacrimal gland inflammation as well as inflammation of the exocrine glands of the pancreas. Both lung and exocrine gland infiltrations are apparent, with infiltrating cells being primarily $\mathrm{CD} 4^{+} \mathrm{CD} 8^{-} \mathrm{T}$ cells. Both salivary and lacrimal glands demonstrate lymphocytic accumulation within periductal areas spanning to the lobules, and lacrimal glands show significant degeneration of acinar cells surrounding infiltrations. Tissue damage is minor or absent in salivary glands of aged mice, and the liver shows mild lymphoid cell infiltration. No autoantibodies to selfantigens or nuclear components are apparent, likely due to extreme defects in humoral immunity.

\section{Transgenic Mouse Models}

3.1. HTLV-1 Tax Transgenic (Tg) Mice. Human T-cell leukemia virus 1 (HTLV-1) is a retrovirus involved in adult T-cell leukemia as well as in the pathogenesis of autoimmune diseases such as SjS, RA, and possibly multiple sclerosis (MS) [65]. Transgenic mice containing the HTLV1 tax gene under the control of the viral long terminal repeat (LTR) acquires an autoimmune phenotype which targeted the exocrine glands [27]. At early age, HTLV-1 tax transgenic mice have rapid proliferation of epithelial cells with subsequent ductal proliferation, causing distortion of the salivary gland architecture. Lymphocytic infiltrations were observed juxtapose to epithelial cells in the salivary and lacrimal glands. However, lacrimal glands develop less severe infiltrations with onset occurring much later than in the salivary glands. Massive LF develop between 6-8 months of age with subsequent destruction of acinar tissues. The degree of destruction corresponds with the level of tax gene expression in the ductal epithelium, suggesting that HTLV1 may be tropic for ductal epithelial cells in the exocrine glands. Therefore, it is postulated that HTLV-1 may trigger the viral induction of inflammatory lesions via initiation of proliferation and lymphocytic infiltrations. However, disease etiology in this mouse model is likely different from that in human pSjS in which lymphocytic infiltration occurs before proliferation of ductal cells.

\subsection{Cytokine Overexpression Models}

3.2.1. IL-6 Transgenic Mice. Interleukin-6 is a cytokine that influences the immune response, participating in 
autoimmune disease development and pathogenesis of liver disease. Using a murine graft-versus-host reaction (GVHR) model with MHC class II disparity, the amount of autoimmune-like lesions were examined to observe a difference in transgenic mice with high IL- 6 concentrations. The GVHR IL-6 transgenic mice had increased IL-6 serum levels and antimitochondrial antibodies (AMA), larger spleen indexes, and weakened autoimmune-like lesions of the liver, pancreas, and salivary glands when compared to controls. There is a discrepancy between AMA titers and histological features in $I L-6 \mathrm{Tg}$ mice, indicating that AMA production may be a result of polyclonal activation of $\mathrm{B}$ cells upon stimulation by IL-6. Results indicate IL-6 may influence the pathogenesis of SjS [32].

3.2.2. IL-10 Transgenic Mice. Interleukin-10 (IL-10) is a cytokine that may contribute to inflammation and pathogenesis in various autoimmune diseases, due to its function in regulating the proliferation and differentiation of $\mathrm{B}$ cells and in enhancing MHC class II antigen expression [66]. IL-10 has also been shown to induce expression of cell adhesion molecules on endothelial cells and to trigger apoptotic cell death [67]. IL-10 Tg mice were generated by using the human salivary amylase promoter to regulate $I L-10$ gene expression [68]. Elevated expression levels of IL-10 are observed in the salivary and lacrimal glands. Histological examination confirmed the presence of inflammatory lesions within the exocrine glands in $8 \mathrm{wks}$ old mice, with concomitant decreased salivary and lacrimal fluid secretion. Staining of lymphocytic infiltrates demonstrated that the cell population was predominantly $\mathrm{CD} 4^{+}$with a lesser portion $(<10 \%)$ of $\mathrm{CD}^{+}$cells. No sex differences were evident. By $20 \mathrm{wks}$ of age, no significant difference was observed between IgG1 levels in wild-type control and transgenic mice and no autoantibodies were detected. Interestingly, $\mathrm{CD} 4^{+} \mathrm{T}$ cells in $I L-10 \mathrm{Tg}$ mice expressed FasL, suggesting that IL-10 may play a part in FasL activation of nonspecific bystander $\mathrm{T}$ cells, which coincides with Fas/FasL-mediated apoptosis in the destruction of acinar tissue.

3.2.3. IL-12 Transgenic Mice. Interleukin-12 (IL-12) is a heterodimeric cytokine produced mainly by activated macrophages, dendritic cells, and granulocytes which functions in the activation of NK cells and induces $\mathrm{CD} 4^{+} \mathrm{T}$ cell differentiation from a $\mathrm{T}_{\mathrm{H}} 0$ to $\mathrm{T}_{\mathrm{H}} 1$ cell phenotype $[69,70]$. IL-12 SJL transgenic mice were made by expressing IL-12 p70 under the transcriptional control of the thyroglobulin promoter, resulting in IL-12 overexpression in the thyroid organ [69]. Histopathological analysis showed an increase in mononuclear infiltrates within salivary and lacrimal glands when compared with wild-type mice. LF consist primarily of $\mathrm{B} 220^{+} \mathrm{B}$ lymphocytes with a lesser amount of $\mathrm{CD} 4^{+} \mathrm{T}$ lymphocytes. Subsequently, the Tg mice develop hyposecretory function in the exocrine glands. Sex-dependent growth retardation was observed in female, but not male mice, suggesting a sex-specific effect of IL-12 overexpression [70]. A significant decrease in saliva flow rate was evident in both sexes; however, in males the decrease was age dependent while in females the change was neither age nor gene dose dependent. Increased levels of ANA were observed at 13 wks, and age-dependent increase in anti-SSB/La autoantibody was also presented; however, no significant difference in antiSSA/Ro autoantibody was seen when compared with wildtype controls. Morphological changes included an increase in acinar cell volume and a decrease in cell number per acinus in the salivary glands [70]. This mouse model tends to develop autoimmune thyroid disease, indicating the $I L$ $12 \mathrm{Tg}$ mouse is a candidate animal model for secondary SjS [69].

3.2.4. IL-14 $\alpha$ Transgenic Mice. Interleukin-14 $\alpha$ (IL-14 $\alpha$ ) is a cytokine produced mainly by $\mathrm{T}$ cells and acts as a B cell growth factor [71]. Increased levels of IL-14 $\alpha$ are present in the peripheral blood leukocytes of both pSjS and secondary SjS patients with SLE [72]. IL-14 $\alpha$ Tg mice develop hypergammaglobulinemia involving IgG, IgA, and IgM autoantibodies, parotid gland lymphocytic infiltrations, deposits of IgM in the kidneys, and mild renal disease. These features are characteristic of human SjS, but also reflect a SLE-like phenotype [73]. Development of large B cell lymphomas in aged $I L-14 \alpha \mathrm{Tg}$ mice occurs as a result of dysregulation of IL-14 $\alpha$ which regulates B lymphocyte growth, a common clinical manifestation in both SjS and SLE patients [73]. IL-14 $\alpha \mathrm{Tg}$ mice also demonstrate enhanced antibody responses to vaccinations with $\mathrm{T}$-independent and T-dependent antigens. Decreased saliva secretion occurs prior to lymphocytic infiltrations of the salivary glands. Tear flow has not been fully defined, although lymphocytic infiltrations do occur in the lacrimal glands. Less than $25 \%$ of $I L-14 \alpha \mathrm{Tg}$ mice test positive for anti-SSA/Ro and antiSSB/La which are detected at 12 months of age in the salivary glands, suggesting that other autoantibodies may contribute to the initial phase of SjS development which remains to be determined [72].

3.2.5. BAFF Transgenic Mice. B-cell activating factor (BAFF) is a ligand in the tumor necrosis factor (TNF) family which acts as a powerful modulator of B cell activity [74]. BAFF is produced by myeloid cells and acts to induce the polyclonal maturation of resting immature B cells to resting mature $\mathrm{B}$ cells without stimulating proliferation [75]. Several autoimmune diseases, including SLE and SjS, have increased blood levels of BAFF, and neutralization of BAFF results in disease prevention [76]. Mice transgenic for BAFF develop an SLE phenotype, presenting with hyperproliferation of B lymphocytes and elevated levels of RF and anti-DNA autoantibodies [77]. As the BAFF Tg mice age, they develop a secondary SjS-like phenotype by 13 months of age with reduced saliva flow, presenting with enlarged salivary glands and corresponding B220 $0^{+}$cells lymphocytic infiltrations with destruction of ductal and acinar cells [78]. Keratoconjunctivitis was not apparent and no sex dimorphism in disease development was observed. BAFF $\mathrm{Tg}$ mice also had severe hypergammaglobulinemia with high levels of immunoglobulins, specifically IgG, IgM, 
$\operatorname{IgA}$, and IgE isotypes; however, neither anti-SSA/Ro or antiSSB/La autoantibodies were detected [79]. Summarized data for spontaneous and transgenic mouse models is presented in Table 3.

\section{Knockout (KO) Mouse Models}

4.1. Id $3^{-/-}$Knockout Mice. Inhibitor of differentiation 3 (Id3) is a nuclear protein which inhibits the DNA binding of basic-helix-loop-helix (bHLH) transcription factors and is involved in both negative and positive regulations of cell growth and differentiation [80]. Id3 is also influential in TCR-mediated $\mathrm{T}$ cell selection during $\mathrm{T}$ cell development [81]. Id3 null mutants develop lymphocytic infiltrations within the salivary and lacrimal glands by 2 months of age, corresponding with a loss in secretory function. Infiltrations are composed mainly of $\mathrm{CD}^{+}$and $\mathrm{CD}^{+} \mathrm{T}$ cells and $\mathrm{B} 220^{+} \mathrm{B}$ cells $[82]$. Both autoantibodies, anti-SSA/Ro and anti-SSB/La, were shown to be present at significant levels after 1 year of age [82]. Notably, infiltrations were not observed in nonexocrine organs. In this model, neonatal 3 day thymectomization or genetic ablation of $\mathrm{T}$ cells resulted in an improvement in disease condition, implying that autoimmune $\mathrm{T}$ cells are of thymic origin. B cells were observed to behave in cooperation with $\mathrm{T}$ cells in the suppression of exocrine function.

4.2. PI3K Knockout Mice. The phosphoinositide 3-kinase (PI3K) enzymes produce 3-phosphorylated phosphoinositides which function as second messengers downstream of multiple receptor types [83]. To create a null mutant for PI3K, a strain with a floxed allele of Pik3r1 and a null allele of Pik3r2 was crossed with Lck-Cre transgenic mice, producing the $\mathrm{r} 1 \Delta \mathrm{T} / \mathrm{r} 2 \mathrm{n}$ strain [84]. The resulting knockout mouse develops an SjS-like autoimmunity, with lymphocytic infiltration of the lacrimal glands and acinar cell atrophy and destruction. Infiltrations in the lacrimal glands consist primarily of $\mathrm{CD}^{+} \mathrm{T}$ cells with a lesser portions of $\mathrm{CD}^{+}$ $\mathrm{T}$ cells and $\mathrm{B} 220^{+} \mathrm{B}$ cells. Infiltrations also occur within the lungs, liver, and intestines, with no inflammation in the kidney, supporting a primary SjS disease.

4.3. TGF- $\beta 1$ Knockout Mice. The multifunctional cytokine, transforming growth factor beta 1 (TGF- $\beta 1$ ), is produced mainly by lymphocytes, macrophages, and dendritic cells and is involved in immunoregulation, embryonic development, hematopoiesis, wound healing, fibrosis, and tumorgenesis [85-89]. Homozygous mutants of the TGF- $\beta 1$ gene experience a rapid onset of severe systemic inflammation which predominantly targets the salivary glands, eyes, heart, skeletal muscle, lungs, liver, stomach, pancreas, and brain [90]. Inflammatory infiltrates vary in cellular compositions across the spectrum of affected organs, from primarily lymphocytic in the brain to primarily neutrophilic in the stomach. Salivary gland infiltrations appear at $1 \mathrm{wk}$ of age and increase in severity with age [91]. Mononuclear lymphocytic infiltration in the salivary gland causes rapid atrophy of acinar tissues and high deposition levels of IgG, TNF$\alpha$, IFN- $\gamma$, IL- $1 \beta$, IL-4, IL-6, and IL-10 in the lesions. Saliva production is significantly affected in TGF- $\beta 1 \mathrm{KO}$ mice when compared to wild-type controls. Peripheral blood analysis of TGF- $\beta 1 \mathrm{KO}$ mice revealed the presence of anti-ssDNA, antidsDNA, ANA, and glomerular immune complex deposits [88]. TGF- $\beta 1$ also affects thymocytes differentiation by inhibition of precursor $\mathrm{CD} 4^{-} \mathrm{CD} 8^{\text {low }}$ thymocytes differentiation into mature $\mathrm{CD} 4^{+} \mathrm{CD} 8^{+}$thymocytes.

4.4. Thrombospondin-1-Deficient Mice. Thrombospondin-1 (TSP-1) is a matricellular protein which regulates both in vitro and in vivo activation of latent TGF- $\beta[92,93]$. Relying on the precise pathogenic effect that TGF- $\beta$ exerts on the autoimmune process of SjS, a TSP-1 deficient mouse strain was created; however, the deficient mice presented with less severe inflammation when compared with the TGF- $\beta$ KO mouse [94]. Inflammatory infiltrates within the lacrimal glands were first observed at $24 \mathrm{wks}$ of age, consisting primarily of $\mathrm{CD}^{+} \mathrm{T}$ cells with a lesser amount of $\mathrm{CD} 8^{+}$ $\mathrm{T}$ cells. TSP-1-deficient mice also demonstrate reduced eye size which occasionally leads to complete closure and loss of eyes. Damage to the corneal epithelial barrier is apparent, occurring in conjunction with corneal edema in aged mice. Both anti-SSA/Ro and anti-SSB/La autoantibodies are detected at elevated levels in the sera, and a significant loss of lacrimal gland secretory function is evident. A twofold increase in IL-17A ${ }^{+}$cells was observed in splenocytes, and increased apoptosis and transcriptional levels of IL- 6 and IFN- $\gamma$ were seen in the lacrimal glands of 8-week- old mice. Also, a considerable increase in $\mathrm{IL}-17 \mathrm{~A}^{+} \mathrm{CD} 4^{+}$peripheral $\mathrm{T}$ cells was apparent in 24 wks old TSP-1-deficient mice, concurrent with reduced levels of IFN- $\gamma$. Currently, it is unknown whether this mouse model develops sialadenitis and secretory dysfunction in the salivary glands.

4.5. Aromatase-Deficient Mice. The aromatase gene controls activation of estrogen production [95]. To determine whether estrogen levels may contribute to SjS disease pathogenesis, an aromatase knock-out (ArKO) mouse model was constructed [96]. Male and female ArKO mice over 12 months old present with mild splenomegaly, lymphadenopathy, and hypercellularity in the bone marrow, with no apparent lymphocytic infiltrations occurring within the lungs and liver. Peripheral blood analysis revealed a 1.5- to 2-fold increase in leukocyte population with a significant increase in the number of $\mathrm{B}_{2} 20^{+} \mathrm{B}$ lymphocytes, but no change in the number of $\mathrm{T}$ cell antigen receptor- $\beta^{+} \mathrm{T}$ cells. Mild proteinuria and massive lymphocyte infiltration within the kidneys suggest renal dysfunction in the ArKO mice. In aged ArKO mice (12-17 months), enlarged salivary glands with massive lymphocytic infiltrations were observed, with severe acinar tissue destruction. The major composition of lymphocytic infiltrations was $\mathrm{B}_{2} 20^{+} \mathrm{B}$ lymphocytes. A significant increase in $\mathrm{B}_{2} 20^{+}$cells was also observed in the lymphoid tissues. Sera analysis revealed the presence of anti- $\alpha$-fodrin autoantibodies, and analysis of infiltrates in salivary glands showed evidence of proteolytic fragments of 


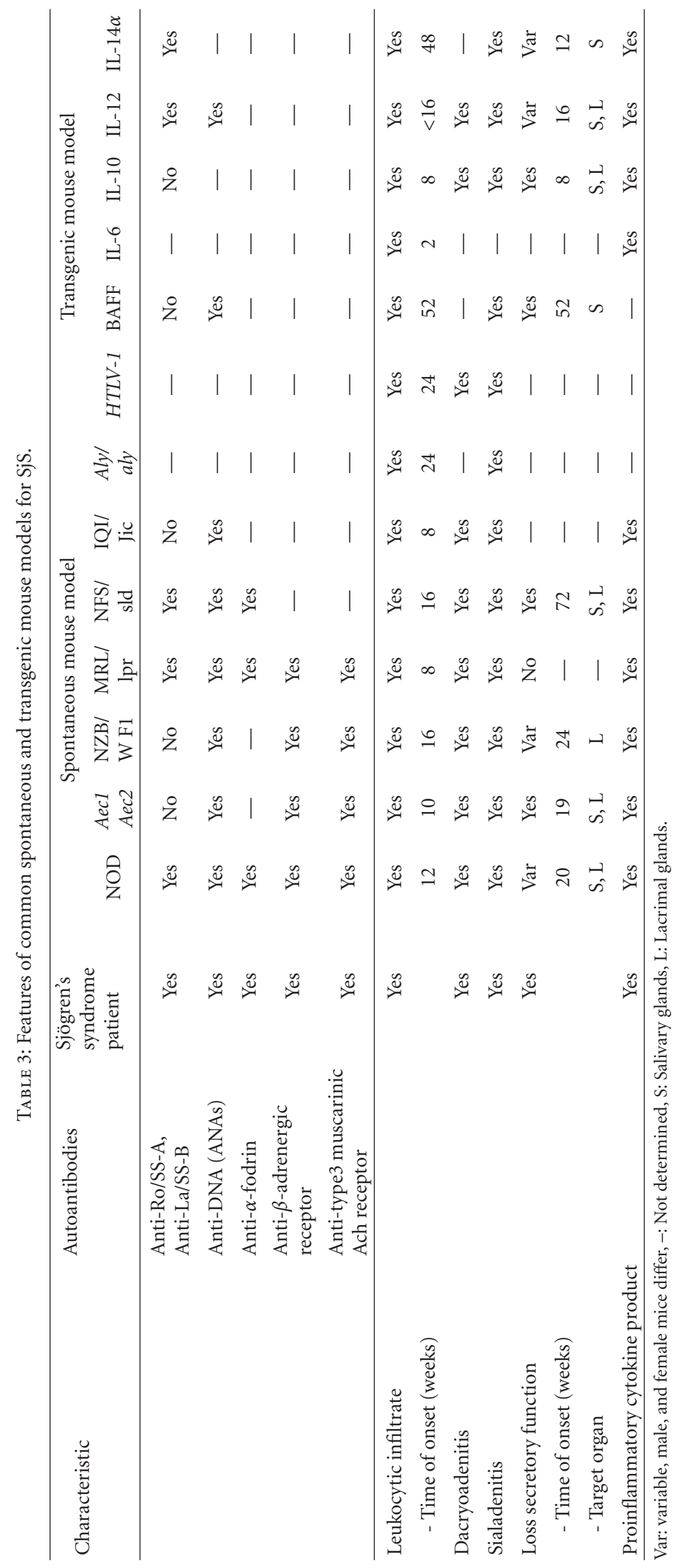


$\alpha$-fodrin, indicative of tissue destruction often present in pSjS. The ArKO mice were negative for ANA and manifested long-term estrogen deprivation resulting in autoimmune exocrinopathy and occasionally renal failure.

\section{Immunization Mouse Models}

5.1. Carbonic Anhydrase II Immunization. Frequently, antibodies to carbonic anhydrase II (CAII), a basic zinc metalloenzyme involved in the catalysis of a reversible hydration of carbon dioxide, are characteristic of autoimmune pancreatitis [97, 98]. However, recent findings suggest their presence in other autoimmune diseases such as SjS as well as connective tissue diseases [99]. Autoimmune sialadenitis was induced in $\mathrm{PL} / \mathrm{J}\left(H-2^{u}\right)$ mice by immunization with human carbonic anhydrase II (CAII) [100]. Mice immunized with CAII developed an increase in the size and focus score in the salivary and lacrimal glands. In addition the animals manifested disintegration and atrophy of surrounding acinar cells [100]. A small percentage of CAII-immunized mice demonstrated smaller LF within the pancreas and kidney, similar to human SjS patients who develop chronic pancreatitis and renal tubular acidosis [100, 101]. Serum antibody reactive to CAII has been reported in several autoimmune diseases, including SjS, chronic pancreatitis (CP), and autoimmune cholangitis [102]. However, no proliferative responses of peripheral blood mononuclear cells (PBMC) to CAII were observed, indicating CAII is probably not a key target antigen for the immune response in the origination and development of SjS and CP [103].

5.2. Ro Immunization. Anti-SSA/Ro autoantibody is present at a significantly high level in patients with severe autoimmune diseases and serves as a standard diagnostic biomarker for SjS and SLE [104]. BALB/c mice immunized with short peptides from the $60-\mathrm{kDA}$ Ro (SSA) antigen, known to induce epitope spreading, develop an immune response to the Ro/La ribonucleoprotein particle [105]. Ro immunized mice present with lymphocytic infiltrations within the salivary glands composed primarily of $\mathrm{CD}^{+}(45 \%)$ and $\mathrm{CD}^{+}(18 \%) \mathrm{T}$ cells and CD19+ $(35 \%)$ B lymphocytes, concurrent with a significant decrease in saliva flow rate [105]. Intermolecular epitopes spreading can be prevented by oral administration of the Ro 60 autoantigen to Ro immunized mice, inhibiting salivary gland lymphocytic infiltrations and increasing salivary flow rate; however, epitope spreading is indicative of minimal tolerance to Ro and La in the B cell and $\mathrm{T}$ cell compartments [106-110]. This model however requires repeated immunizations with Ro peptide emulsified in Freund's adjuvant over the course of several wks, with disease development not occurring until 4 months, raising the issue of a completely different etiological scenario than is seen in human SjS patients [111]. The role of anti-SSA/Ro is not well understood in either SjS mouse models or in human SjS patients; therefore, further study is needed to examine the pathogenic role of Ro antigen.

\section{Infection Mouse Models}

6.1. Murine Cytomegalovirus. Environmental triggers have been postulated to be capable of inducing autoimmunity in genetically predisposed individuals. Several viruses including Epstein-Barr virus (EBV), hepatitis C virus, and cytomegalovirus (CMV) have been associated with the development of SjS. Frequently, individuals who are immunocompromised develop sialadenitis upon CMV infection due to viral replication which occurs primarily within the ductal epithelium of the salivary glands [112]. In mice, however, murine CMV (MCMV) instead replicates within the serous acinar epithelial cells of the submandibular gland [113-115]. Salivary gland infection in mice produces an extended inflammatory immune response which leads to epithelial cell death and regeneration [116]. Four different strains of mice (C57BL/6 [B6]-+/+, Fas-deficient B6-lpr/lpr, TNFRI-deficient B6-tn $f r 1^{0 / 0}$, and B6-tn $f r 1^{0 / 0}$ lpr/lpr) infected with murine CMV (MCMV) were shown to manifest certain phenotypes of SjS-like disease [117]. For instance, Fas-deficient B6-lpr/lpr mice infected with murine CMV (MCMV) developed anti-Ro and anti-La autoantibodies and persistent severe lymphocytic infiltrations within the salivary glands that remained 100 days postinfection even after viral clearance. Neither C57BL/6 [B6]-+/+ nor TNFRI-deficient B6-tn $\mathrm{fr}^{0 / 0}$ mice infected with MCMV had inflammation in the salivary glands at 100 days postinfection, although infiltrations were observed in both strains at 28 days postinfection. In MCMV-infected B6tn $f r 1^{0 / 0}$-lpr/lpr mice, identical salivary gland inflammation to MCMV-infected B6-lpr/lpr mice was observed at 28 days, and no inflammation was apparent in uninfected B6-lpr/lpr controls. All mice developed sialadenitis by 28 days which was still present at 100 days postinfection.

Autoimmune-prone NZM2328 mice infected with MCMV are also capable of recapitulating certain phenotypes of SjS-like disease [118]. Infected female NZM2328 mice have severe chronic lymphocytic infiltrations in the exocrine glands composed of CD $4^{+} \mathrm{T}$ cells and $\mathrm{B} 220^{+} \mathrm{B}$ cells. Severe local inflammations coincide with presence of organtargeted autoantibodies against glandular antigens as well as reduced saliva volumes. Anti-Ro/SSA or anti-La/SSB is not detected in virus-infected animals. However, both infected male NZM2328 mice and female B6-lpr mice have significantly less severe glandular infiltrations. Interestingly, animal models of MCMV-induced SjS only require a single exposure to the virus which could serve as an ideal animal model examining the early phase of human SjS development.

\section{Transplantation Chimeras}

Autoimmunity resembling a SjS phenotype can be induced in hybrid mice upon transplantation of leukocytes from a parental strain to nonirradiated $\mathrm{F} 1$ recipients, generating a chronic graft-versus-host reaction (GVHR) [119-121]. Haematopoietic transplantation chimeras were produced by transplantation of spleen cells from $\mathrm{BALB} / \mathrm{c}$ donors to nonirradiated $\mathrm{F}_{1}$-hybrids of $\mathrm{BALB} / \mathrm{c}$ and $\mathrm{CBA} / \mathrm{H}-\mathrm{T} 6$ mice 


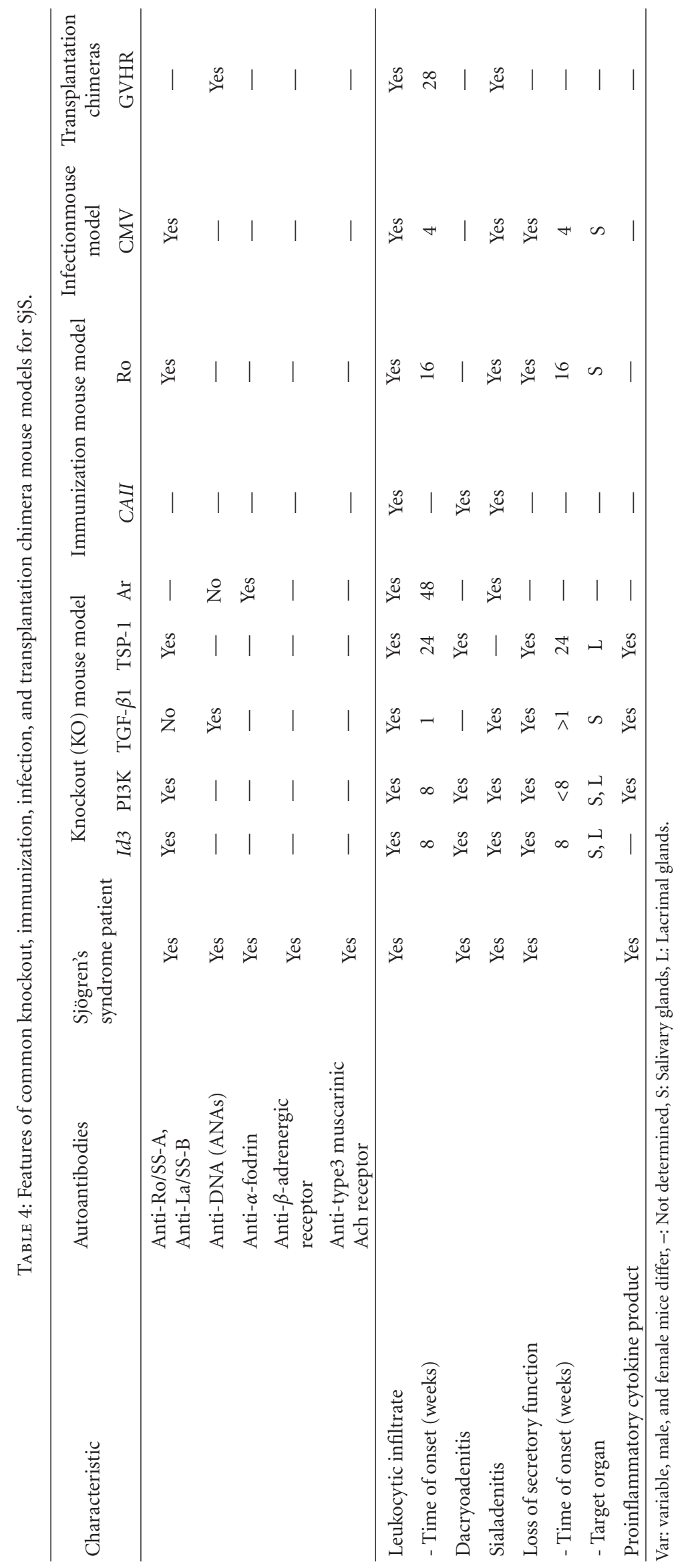


[122]. Both male and female chimeras were shown to subsequently develop a SjS-like phenotype with enlarged lymph nodes and nodulated contorted spleens at 7 months after transplantation. Males manifested a more severe disease phenotype found in the lymph nodes and spleen when compared to both female chimeras and wild type controls. Sera were negative for autoantibodies against DNA, but positive ANA with a nucleolar pattern was observed in most chimeric mice. Raised levels of albumin in the urine of both males and females were found, with higher levels in males. Kidneys in both sexes demonstrated lymphocyte "cuffs" with plasma cells surrounding the vessels and no $\operatorname{IgG}$, IgA, or IgM deposits were found in glomeruli. Mononuclear cell infiltrates were apparent in both the salivary and lacrimal glands of male and female chimeras with no difference in severity between sexes. The spleens showed ordinary size and distribution of red pulp, but diminished or absent white pulp. The rim of lymphocytes was absent, and cells were enlarged within the germinal centers. The nodules in the spleen indicate that donor spleen colony-forming units have invaded the recipient spleen, resulting in competition with lymphohaematopoietic cells [122]. Therefore, it is likely that transplantation leads to both acute and chronic GVHR. The chimeric animals showed the absence of typical clinical phenotypes of SjS, including splenomegaly, hepatomegaly, high albuminuria, anti-dsDNA autoantibodies, ascites formation, and immune complex glomerulonephritis [122]. Summarized data for knockout, immunization, infection, and transplantation chimera mouse models is presented in Table 4 .

\section{Conclusion and Future Directions}

As demonstrated by the vast range of available mouse models, SjS is a highly complex disease whose etiology is still not well understood. It is likely that $\mathrm{SjS}$ pathogenesis involves an intricate relationship between genetics and environmental factors which can provoke both innate and adaptive immunity, hormone secretion, and the autonomic nervous system into triggering the initiation and progression of the disease. Animal models demonstrate a variety of potential pathologies for the disease, ranging from overproduction of inflammatory cytokines to exposure by exocrine glandtargeting viruses. Therefore, these animal models provide a useful tool in observing the different stages in the glandular pathophysiological abnormality to the loss of immune tolerance and eventually to the onset of overt or clinical disease. In addition, they can serve as great tools in designing diagnoses, as well as in prevention and treatment therapies. Each mouse model possesses its own advantages, as well as pitfalls, and no ideal model for the study of SjS currently exists. Spontaneous models naturally develop SjS and appear most similar to the human SjS disease, but still have their drawbacks. Knock-out animal models can also be useful, allowing observation of the importance a particular protein, regulatory mechanism, or cell type has in disease development, leading to improved treatment options. However, no SjS mouse model fulfills all of the necessary characteristics of the human disease, and such discrepancies may cause progress in the field to come to a standstill. A better model is needed.

\section{Acknowledgments}

Cuong Q. Nguyen is supported in part by PHS Grants K99DE018958 and R21AI081952, and funds from the Center for Orphan Autoimmune Disorders at University of Florida and the Sjögren's Syndrome Foundation. The authors would like to thank Dr. Ammon B. Peck for helpful suggestions and editorial support. Publication of this article was funded in part by the University of Florida Open-Access publishing Fund.

\section{References}

[1] R. I. Fox, "Sjögren's syndrome," The Lancet, vol. 366, no. 9482, pp. 321-331, 2005.

[2] E. B. Perez, A. Kraus, G. Lopez, M. Cifuentes, and D. AlarconSegovia, "Autoimmune thyroid disease in primary Sjogren's syndrome," American Journal of Medicine, vol. 99, no. 5, pp. 480-484, 1995.

[3] C. V. Strimlan, E. C. Rosenow, and M. B. E. G. Divertie and Harrison, "Pulmonary manifestations of Sjogren's syndrome," Chest, vol. 70, no. 3, pp. 354-361, 1976.

[4] M. J. Kaplan and R. W. Ike, "The liver is a common nonexocrine target in primary Sjögren's syndrome: a retrospective review," BMC Gastroenterology, vol. 2, p. 21, 2002.

[5] W. H. Tu, M. A. Shearn, J. C. Lee, and J. Hopper, "Interstitial nephritis in Sjögren's syndrome," Annals of Internal Medicine, vol. 69 , no. 6, pp. 1163-1170, 1968.

[6] C. G. Helmick, D. T. Felson, R. C. Lawrence et al., "Estimates of the prevalence of arthritis and other rheumatic conditions in the United States. Part I," Arthritis and Rheumatism, vol. 58, no. 1, pp. 15-25, 2008.

[7] N. Talal, “Overview of Sjögren's syndrome," Journal of Dental Research, vol. 66, pp. 672-674, 1987.

[8] A. Prabu, T. Marshall, C. Gordon et al., "Use of patient age and anti-Ro/La antibody status to determine the probability of patients with systemic lupus erythematosus and sicca symptoms fulfilling criteria for secondary Sjögren's syndrome," Rheumatology, vol. 42, no. 1, pp. 189-191, 2003.

[9] S. R. Reader, H. M. Whyte, and P. C. Elmes, "Sjogren's disease and rheumatoid arthritis," Annals of the Rheumatic Diseases, vol. 10, no. 3, pp. 288-297, 1951.

[10] T. H. Kirkham, "Scleroderma and Sjögren's syndrome," British Journal of Ophthalmology, vol. 53, no. 2, pp. 131-133, 1969.

[11] K. S. Culp, C. R. Fleming, and J. Duffy, "Autoimmune associations in primary biliary cirrhosis," Mayo Clinic Proceedings, vol. 57, no. 6, pp. 365-370, 1982.

[12] F. N. Skopouli, P. C. Fox, V. Galanopoulou, J. C. Atkinson, E. S. Jaffe, and H. M. Moutsopoulos, "T cell subpopulations in the labial minor salivary gland histopathologic lesion of Sjogren's syndrome," Journal of Rheumatology, vol. 18, no. 2, pp. 210-214, 1991.

[13] T. C. Adamson, R. I. Fox, D. M. Frisman, and F. V. Howell, "Immunohistologic analysis of lymphoid infiltrates in primary Sjogren's syndrome using monoclonal antibodies," Journal of Immunology, vol. 130, no. 1, pp. 203-208, 1983.

[14] M. N. Manoussakis, S. Boiu, P. Korkolopoulou et al., "Rates of infiltration by macrophages and dendritic cells and expression of interleukin-18 and interleukin-12 in the chronic inflammatory lesions of Sjögren's syndrome: correlation with certain features of immune hyperactivity and factors associated with high risk of lymphoma development," 
Arthritis and Rheumatism, vol. 56, no. 12, pp. 3977-3988, 2007.

[15] C. Vitali, S. Bombardieri, R. Jonsson et al., "Classification criteria for Sjögren's syndrome: a revised version of the European criteria proposed by the American-European Consensus Group," Annals of the Rheumatic Diseases, vol. 61, no. 6, pp. 554-558, 2002.

[16] D. Cavill, S. A. Waterman, and T. P. Gordon, "Antibodies raised against the second extracellular loop of the human muscarinic M3 receptor mimic functional autoantibodies in Sjögren's syndrome," Scandinavian Journal of Immunology, vol. 59, no. 3, pp. 261-266, 2004.

[17] S. Cha, E. Singson, J. Cornelius, J. P. Yagna, H. J. Knot, and A. B. Peck, "Muscarinic acetylcholine type-3 receptor desensitization due to chronic exposure to Sjögren's syndromeassociated autoantibodies," Journal of Rheumatology, vol. 33, no. 2, pp. 296-306, 2006.

[18] L. J. Dawson, H. E. Allison, J. Stanbury, D. Fitzgerald, and P. M. Smith, "Putative anti-muscarinic antibodies cannot be detected in patients with primary Sjögren's syndrome using conventional immunological approaches," Rheumatology, vol. 43, no. 12, pp. 1488-1495, 2004.

[19] L. J. Dawson, E. A. Field, A. R. Harmer, and P. M. Smith, "Acetylcholine-evoked calcium mobilization and ion channel activation in human labial gland acinar cells from patients with primary Sjögren's syndrome," Clinical and Experimental Immunology, vol. 124, no. 3, pp. 480-485, 2001.

[20] J. Gao, S. Cha, R. Jonsson, J. Opalko, and A. B. Peck, "Detection of anti-type 3 muscarinic acetylcholine receptor autoantibodies in the sera of Sjögren's syndrome patients by use of a transfected cell line assay," Arthritis and Rheumatism, vol. 50, no. 8, pp. 2615-2621, 2004.

[21] J. Li, Y. M. Ha, NA. Y. Kü et al., "Inhibitory effects of autoantibodies on the muscarinic receptors in Sjögren's syndrome," Laboratory Investigation, vol. 84, no. 11, pp. 1430-1438, 2004.

[22] A. J. Smith, M. W. Jackson, F. Wang, D. Cavill, M. Rischmueller, and T. P. Gordon, "Neutralization of muscarinic receptor autoantibodies by intravenous immunoglobulin in Sjögren syndrome," Human Immunology, vol. 66, no. 4, pp. 411-416, 2005.

[23] F. Wang, M. W. Jackson, V. Maughan et al., "Passive transfer of Sjögren's syndrome IgG produces the pathophysiology of overactive bladder," Arthritis and Rheumatism, vol. 50, no. 11, pp. 3637-3645, 2004.

[24] S. A. Waterman, T. P. Gordon, and M. Rischmueller, "Inhibitory effects of muscarinic receptor autoantibodies on parasympathetic neurotransmission in Sjogren's syndrome," Arthritis and Rheumatism, vol. 43, no. 7, pp. 1647-1654, 2000.

[25] S. C. Pflugfelder, C. A. Crouse, D. Monroy, M. Yen, M. Rowe, and S. S. Atherton, "Epstein-Barr virus and the lacrimal gland pathology of Sjögren's syndrome," American Journal of Pathology, vol. 143, no. 1, pp. 49-64, 1993.

[26] J. Haddad, P. Deny, C. Munz-Gotheil et al., "Lymphocytic sialadenitis of Sjogren's syndrome associated with chronic hepatitis C virus liver disease," The Lancet, vol. 339, no. 8789, pp. 321-323, 1992.

[27] J. E. Green, S. H. Hinrichs, J. Vogel, and G. Jay, "Exocrinopathy resembling Sjogren's syndrome in HTLV-1 tax transgenic mice," Nature, vol. 341, no. 6237, pp. 72-74, 1989.
[28] D. L. Moyes, A. Martin, S. Sawcer et al., "The distribution of the endogenous retroviruses HERV-K113 and HERV-K115 in health and disease," Genomics, vol. 86, no. 3, pp. 337-341, 2005.

[29] C. Q. Nguyen and A. B. Peck, "Unraveling the pathophysiology of Sjogren syndrome-associated dry eye disease," Ocular Surface, vol. 7, no. 1, pp. 11-27, 2009.

[30] Y. Iwakura, S. Saijo, Y. Kioka et al., "Autoimmunity induction by human $\mathrm{T}$ cell leukemia virus type 1 in transgenic mice that develop chronic inflammatory arthropathy resembling rheumatoid arthritis in humans," Journal of Immunology, vol. 155, no. 3, pp. 1588-1598, 1995.

[31] H. Dang, A. G. Geiser, J. J. Letterio et al., "SLE-like autoantibodies and Sjogren's syndrome-like lymphoproliferation in TGF- $\beta$ knockout mice," Journal of Immunology, vol. 155, no. 6, pp. 3205-3212, 1995.

[32] T. Kimura, K. Suzuki, S. Inada et al., "Induction of autoimmune disease by graft-versus-host reaction across MHC class II difference: modification of the lesions in IL-6 transgenic mice," Clinical and Experimental Immunology, vol. 95, no. 3, pp. 525-529, 1994.

[33] S. Makino, K. Kunimoto, and Y. Muraoka, "Breeding of a non-obese, diabetic strain of mice," Experimental Animals, vol. 29, no. 1, pp. 1-13, 1980.

[34] J. F. Bach, "Insulin-dependent diabetes mellitus as an autoimmune disease," Endocrine Reviews, vol. 15, no. 4, pp. 516-542, 1994.

[35] Y. Hu, Y. Nakagawa, K. R. Purushotham, and M. G. Humphreys-Beher, "Functional changes in salivary glands of autoimmune disease-prone NOD mice," American Journal of Physiology, vol. 263, no. 4, pp. E607-E614, 1992.

[36] M. G. Humphreys-Beher, "Animal models for autoimmune disease-associated xerostomia and xerophthalmia," Advances in Dental Research, vol. 10, no. 1, pp. 73-75, 1996.

[37] J. Brayer, J. Lowry, S. Cha et al., "Alleles from chromosomes 1 and 3 of NOD mice combine to influence Sjogren's syndrome-like autoimmune exocrinopathy," Journal of Rheumatology, vol. 27, no. 8, pp. 1896-1904, 2000.

[38] W. M. Ridgway, L. B. Peterson, J. A. Todd et al., "Chapter 6 gene-gene interactions in the NOD mouse model of type 1 diabetes," Advances in Immunology, vol. 100, pp. 151-175, 2008.

[39] S. Cha, H. Nagashima, V. B. Brown, A. B. Peck, and M. G. Humphreys-Beher, "Two NOD Idd-associated intervals contribute synergistically to the development of autoimmune exocrinopathy (Sjögren's syndrome) on a healthy murine background," Arthritis and Rheumatism, vol. 46, no. 5, pp. 1390-1398, 2002.

[40] C. Q. Nguyen, M. H. Hu, YI. Li, C. Stewart, and A. B. Peck, "Salivary gland tissue expression of interleukin-23 and interleukin-17 in Sjögren's syndrome: findings in humans and mice," Arthritis and Rheumatism, vol. 58, no. 3, pp. 734743, 2008.

[41] C. Nguyen, C. Nguyen, E. Singson et al., "Sjögren's syndrome-like disease of C57BL/6.NOD-Aec1 Aec2 mice: gender differences in keratoconjunctivitis sicca defined by a cross-over in the chromosome 3 Aec1 locus," Scandinavian Journal of Immunology, vol. 64, no. 3, pp. 295-307, 2006.

[42] L. Kong, C. P. Robinson, A. B. Peck et al., "Inappropriate apoptosis of salivary and lacrimal gland epithelium of immunodeficient NOD-scid mice," Clinical and Experimental Rheumatology, vol. 16, no. 6, pp. 675-681, 1998. 
[43] Y. Oppenheim, G. Kim, Y. Ban et al., "The Effects of Alpha interferon on the development of autoimmune thyroiditis in the NOD H2h4 Mouse," Clinical and Developmental Immunology, vol. 10, no. 2-4, pp. 161-165, 2003.

[44] P. L. Podolin, A. Pressey, N. H. DeLarato, P. A. Fischer, L. B. Peterson, and L. S. Wicker, "I-E nonobese diabetic mice develop insulitis and diabetes," Journal of Experimental Medicine, vol. 178, no. 3, pp. 793-803, 1993.

[45] C. Carnaud, B. Legrand, M. Olivi, L. B. Peterson, L. S. Wicker, and J. F. Bach, "Acquired allo-tolerance to major or minor histocompatibility antigens indifferently contributes to preventing diabetes development in non-obese diabetic (NOD) mice," Journal of Autoimmunity, vol. 5, no. 5, pp. 591$601,1992$.

[46] C. P. Robinson, S. Yamachika, D. I. Bounous et al., "A novel NOD-derived murine model of primary Sjogren's syndrome," Arthritis and Rheumatism, vol. 41, no. 1, pp. 150156, 1998.

[47] H. S. Kessler, "A laboratory model for Sjögren's syndrome," American Journal of Pathology, vol. 52, no. 3, pp. 671-685, 1968.

[48] R. Jonsson, A. Tarkowski, K. Backman, and L. Klareskog, "Immunohistochemical characterization of sialadenitis in NZB $x$ NZW F mice," Clinical Immunology and Immunopathology, vol. 42, no. 1, pp. 93-101, 1987.

[49] R. J. Harbeck, T. Launder, and C. Staszak, "Mononuclear cell pulmonary vasculitis in NZB/W mice. II. Immunohistochemical characterization of the infiltrating cells," American Journal of Pathology, vol. 123, no. 2, pp. 204-211, 1986.

[50] C. Staszak and R. J. Harbeck, "Mononuclear-cell pulmonary vasculitis in NZB/W mice. I. Histopathologic evaluation of spontaneously occurring pulmonary infiltrates," American Journal of Pathology, vol. 120, no. 1, pp. 99-105, 1985.

[51] R. Watanabe-Fukunaga, C. I. Brannan, N. G. Copeland, N. A. Jenkins, and S. Nagata, "Lymphoproliferation disorder in mice explained by defects in Fas antigen that mediates apoptosis," Nature, vol. 356, no. 6367, pp. 314-317, 1992.

[52] B. Andrews, R. A. Eisenberg, and A. N. Theofilopoulos, "Spontaneous murine lupus-like syndromes. Clinical and immunopathological manifestations in several strains," Journal of Experimental Medicine, vol. 148, no. 5, pp. 1198-1215, 1978.

[53] L. Hang, A. N. Theofilopoulos, and F. J. Dixon, "A spontaneous rheumatoid arthritis-like disease in MRL/1 mice," Journal of Experimental Medicine, vol. 155, no. 6, pp. 16901701, 1982.

[54] R. Jonsson, A. Tarkowski, and K. Backman, "Sialadenitis in the MRL-1 mouse: morphological and immunohistochemical characterization of resident and infiltrating cells," Immunology, vol. 60, no. 4, pp. 611-616, 1987.

[55] R. W. Hoffman, M. A. Alspaugh, and K. S. Waggie, "Sjogren's syndrome in MRL/l and MRL/n mice," Arthritis and Rheumatism, vol. 27, no. 2, pp. 157-165, 1984.

[56] M. Wahren, K. Skarstein, I. Blange, I. Pettersson, and R. Jonsson, "MRL/lpr mice produce anti-Ro $52000 \mathrm{MW}$ antibodies: detection, analysis of specificity and site of production," Immunology, vol. 83, no. 1, pp. 9-15, 1994.

[57] Y. Hayashi, A. Kojima, M. Hata, and K. Hirokawa, "A new mutation involving the sublingual gland in NFS/N mice. Partially arrested mucous cell differentiation," American Journal of Pathology, vol. 132, no. 2, pp. 187-191, 1988.
[58] N. Haneji, H. Hamano, K. Yanagi, and Y. Hayashi, "A new animal model for primary Sjogren's syndrome in NFS/sld mutant mice," Journal of Immunology, vol. 153, no. 6, pp. 2769-2777, 1994.

[59] N. Haneji, T. Nakamura, K. Takio et al., "Identification of $\alpha$-fodrin as a candidate autoantigen in primary Sjogren's syndrome," Science, vol. 276, no. 5312, pp. 604-607, 1997.

[60] N. Ishimaru, T. Yoneda, K. Saegusa et al., "Severe destructive autoimmune lesions with aging in murine Sjogren's syndrome through Fas-mediated apoptosis," American Journal of Pathology, vol. 156, no. 5, pp. 1557-1564, 2000.

[61] J. Saegusa and H. Kubota, "Sialadenitis in IQI/Jic Mice: a new animal model of Sjögren's syndrome," Journal of Veterinary Medical Science, vol. 59, no. 10, pp. 897-903, 1997.

[62] K. Takada, M. Takiguchi, A. Konno, and M. Inaba, "Spontaneous development of multiple glandular and extraglandular lesions in aged IQI/Jic mice: a model for primary Sjögren's syndrome," Rheumatology, vol. 43, no. 7, pp. 858-862, 2004.

[63] K. Takada, M. Takiguchi, A. Konno, and M. Inaba, "Autoimmunity against a tissue kallikrein in IQI/Jic mice: a model for sjögren's syndrome," Journal of Biological Chemistry, vol. 280, no. 5, pp. 3982-3988, 2005.

[64] R. Tsubata, T. Tsubata, H. Hiai et al., "Autoimmune disease of exocrine organs in immunodeficient alymphoplasia mice: a spontaneous model for Sjogren's syndrome," European Journal of Immunology, vol. 26, no. 11, pp. 2742-2748, 1996.

[65] D. Zucker-Franklin, "Non-HIV retroviral associations with rheumatic disease," Current Rheumatology Reports, vol. 2, no. 2, pp. 156-162, 2000.

[66] H. Spits and R. De Waal Malefyt, "Functional characterization of human IL-10," International Archives of Allergy and Immunology, vol. 99, no. 1, pp. 8-15, 1992.

[67] A. C. Fluckiger, I. Durand, and J. Banchereau, "Interleukin 10 induces apoptotic cell death of B-chronic lymphocytic leukemia cells," Journal of Experimental Medicine, vol. 179, no. 1, pp. 91-99, 1994.

[68] I. Saito, K. Haruta, M. Shimuta et al., "Fas ligand-mediated exocrinopathy resembling Sjogren's syndrome in mice transgenic for IL-10," Journal of Immunology, vol. 162, no. 5, pp. 2488-2494, 1999.

[69] H. Kimura, S. C. Tzou, R. Rocchi et al., "Interleukin (IL)-12driven primary hypothyroidism: the contrasting roles of two Th1 cytokines (IL-12 and interferon- $\gamma$ )," Endocrinology, vol. 146, no. 8, pp. 3642-3651, 2005.

[70] J. L. Vosters, M. A. Landek-Salgado, H. Yin et al., "Interleukin-12 induces salivary gland dysfunction in transgenic mice, providing a new model of Sjögren's syndrome," Arthritis and Rheumatism, vol. 60, no. 12, pp. 3633-3641, 2009.

[71] J. L. Ambrus, J. Pippin, A. Joseph et al., "Identification of a cDNA for a human high-molecular-weight B-cell growth factor," Proceedings of the National Academy of Sciences of the United States of America, vol. 90, no. 13, pp. 6330-6334, 1993.

[72] L. Shen, L. Suresh, H. Li et al., "IL-14 alpha, the nexus for primary Sjögren's disease in mice and humans," Clinical Immunology, vol. 130, no. 3, pp. 304-312, 2009.

[73] L. Shen, C. Zhang, T. Wang et al., "Development of autoimmunity in IL-14 $\alpha$-transgenic mice," Journal of Immunology, vol. 177, no. 8, pp. 5676-5686, 2006.

[74] F. MacKay and P. Schneider, "Cracking the BAFF code," Nature Reviews Immunology, vol. 9, no. 7, pp. 491-502, 2009. 
[75] A. G. Rolink, J. Tschopp, P. Schneider, and F. Melchers, "BAFF is a survival and maturation factor for mouse B cells," European Journal of Immunology, vol. 32, no. 7, pp. 2004 2010, 2002.

[76] F. Melchers, "Actions of BAFF in B cell maturation and its effects on the development of autoimmune disease," Annals of the Rheumatic Diseases, vol. 62, no. 2, pp. 25-27, 2003.

[77] F. Mackay, S. A. Woodcock, P. Lawton et al., "Mice transgenic for BAFF develop lymphocytic disorders along with autoimmune manifestations," Journal of Experimental Medicine, vol. 190, no. 11, pp. 1697-1710, 1999.

[78] J. Groom, S. L. Kalled, A. H. Cutler et al., "Association of BAFF/BLyS overexpression and altered B cell differentiation with Sjögren's syndrome," Journal of Clinical Investigation, vol. 109, no. 1, pp. 59-68, 2002.

[79] S. D. Khare, I. Sarosi, X. Z. Xia et al., "Severe B cell hyperplasia and autoimmune disease in TALL-1 transgenic mice," Proceedings of the National Academy of Sciences of the United States of America, vol. 97, no. 7, pp. 3370-3375, 2000.

[80] Y. Yokota, "Id and development," Oncogene, vol. 20, no. 58, pp. 8290-8298, 2001.

[81] G. Bain, C. B. Cravatt, C. Loomans, J. Alberola-Ila, S. M. Hedrick, and C. Murre, "Regulation of the helix-loop-helix proteins, E2A and Id3, by the Ras-ERK MAPK cascade," Nature Immunology, vol. 2, no. 2, pp. 165-171, 2001.

[82] H. Li, M. Dai, and Y. Zhuang, "A T cell intrinsic role of Id3 in a mouse model for primary Sjögren's syndrome," Immunity, vol. 21, no. 4, pp. 551-560, 2004.

[83] J. A. Deane, M. J. Trifilo, C. M. Yballe, S. Choi, T. E. Lane, and D. A. Fruman, "Enhanced T cell proliferation in mice lacking the p85 $\beta$ subunit of phosphoinositide 3-kinase," Journal of Immunology, vol. 172, no. 11, pp. 6615-6625, 2004.

[84] J. S. Oak, J. A. Deane, M. G. Kharas et al., "Sjögren's syndrome-like disease in mice with $\mathrm{T}$ cells lacking class 1A phosphoinositide-3-kinase," Proceedings of the National Academy of Sciences of the United States of America, vol. 103, no. 45, pp. 16882-16887, 2006.

[85] A. Fontana, D. B. Constam, K. Frei, U. Malipiero, and H. W. Pfister, "Modulation of the immune response by transforming growth factor beta," International Archives of Allergy and Immunology, vol. 99, no. 1, pp. 1-7, 1992.

[86] M. M. Shull, I. Ormsby, A. B. Kier et al., "Targeted disruption of the mouse transforming growth factor- $\beta 1$ gene results in multifocal inflammatory disease," Nature, vol. 359, no. 6397, pp. 693-699, 1992.

[87] J. J. Letterio and A. B. Roberts, "Regulation of immune responses by TGF- $\beta$," Annual Review of Immunology, vol. 16, pp. 137-161, 1998.

[88] G. J. Prud'homme and C. A. Piccirillo, "The inhibitory effects of transforming growth factor-beta-1 (TGF- $\beta 1$ ) in autoimmune diseases," Journal of Autoimmunity, vol. 14, no. 1, pp. 23-42, 2000.

[89] P. Schmid, D. Cox, G. Bilbe, R. Maier, and G. K. McMaster, "Differential expression of TGF $\beta 1, \beta 2$ and $\beta 3$ genes during mouse embryogenesis," Development, vol. 111, no. 1, pp. 117-130, 1991.

[90] A. B. Kulkarni, C. G. Huh, D. Becker et al., "Transforming growth factor $\beta$ null mutation in mice causes excessive inflammatory response and early death," Proceedings of the National Academy of Sciences of the United States of America, vol. 90, no. 2, pp. 770-774, 1993.
[91] N. L. McCartney-Francis, D. E. Mizel, R. S. Redman et al., "Autoimmune Sjögren's-like lesions in salivary glands of TGF- $\beta 1$-deficient mice are inhibited by adhesion-blocking peptides," Journal of Immunology, vol. 157, no. 3, pp. 13061312, 1996.

[92] S. E. Crawford, V. Stellmach, J. E. Murphy-Ullrich et al., "Thrombospondin-1 is a major activator of TGF- $\beta 1$ in vivo," Cell, vol. 93, no. 7, pp. 1159-1170, 1998.

[93] S. M. F. Ribeiro, M. Poczatek, S. Schultz-Cherry, M. Villain, and J. E. Murphy-Ullrich, "The activation sequence of thrombospondin-1 interacts with the latency- associated peptide to regulate activation of latent transforming growth factor- $\beta$," Journal of Biological Chemistry, vol. 274, no. 19, pp. 13586-13593, 1999.

[94] B. Turpie, T. Yoshimura, A. Gulati, J. D. Rios, D. A. Dartt, and S. Masli, "Sjögren's syndrome-like ocular surface disease in thrombospondin-1 deficient mice," American Journal of Pathology, vol. 175, no. 3, pp. 1136-1147, 2009.

[95] O. K. Öz, G. Hirasawa, J. Lawson et al., "Bone phenotype of the aromatase deficient mouse," Journal of Steroid Biochemistry and Molecular Biology, vol. 79, no. 1-5, pp. 49-59, 2001.

[96] G. J. Shim, M. Warner, H. J. Kim et al., "Aromatase-deficient mice spontaneously develop a lymphoproliferative autoimmune disease resembling Sjögren's syndrome," Proceedings of the National Academy of Sciences of the United States of America, vol. 101, no. 34, pp. 12628-12633, 2004.

[97] P. Dite, I. Novotny, J. Trna, and A. Sevcikova, "Autoimmune pancreatitis," Best Practice and Research in Clinical Gastroenterology, vol. 22, no. 1, pp. 131-143, 2008.

[98] Y. Inagaki, Y. Jinno-Yoshida, Y. Hamasaki, and H. Ueki, "A novel autoantibody reactive with carbonic anhydrase in sera from patients with systemic lupus erythematosus and Sjogren's syndrome," Journal of Dermatological Science, vol. 2, no. 3, pp. 147-154, 1991.

[99] D. Caccavo, A. Afeltra, A. Rigon et al., "Antibodies to carbonic anhydrase in patients with connective tissue diseases: relationship with lung involvement," International Journal of Immunopathology and Pharmacology, vol. 21, no. 3, pp. 659667, 2008.

[100] I. Nishimori, T. Bratanova, I. Toshkov et al., "Induction of experimental autoimmune sialoadenitis by immunization of $\mathrm{PL} / \mathrm{J}$ mice with carbonic anhydrase II," Journal of Immunology, vol. 154, no. 9, pp. 4865-4873, 1995.

[101] C. Scully, "Sjogren's syndrome: clinical and laboratory features, immunopathogenesis, and management," Oral Surgery Oral Medicine and Oral Pathology, vol. 62, no. 5, pp. 510-523, 1986.

[102] J. Kino-Ohsaki, I. Nishimori, M. Morita et al., "Serum antibodies to carbonic anhydrase I and II in patients with idiopathic chronic pancreatitis and Sjogren's syndrome," Gastroenterology, vol. 110, no. 5, pp. 1579-1586, 1996.

[103] I. Nishimori, E. Miyaji, K. Morimoto, T. Kohsaki, N. Okamoto, and S. Onishi, "Diminished cellular immune response to carbonic anhydrase II in patients with Sjögren's syndrome and idiopathic chronic pancreatitis," Journal of the Pancreas, vol. 5, no. 4, pp. 186-192, 2004.

[104] J. B. Harley and K. K. Gaither, "Autoantibodies," Rheumatic Disease Clinics of North America, vol. 14, no. 1, pp. 43-56, 1988.

[105] R. H. Scofield, S. Asfa, D. Obeso, R. Jonsson, and B. T. Kurien, "Immunization with short peptides from the 60$\mathrm{kDa}$ Ro antigen recapitulates the serological and pathological 
findings as well as the salivary gland dysfunction of Sjögren's syndrome," Journal of Immunology, vol. 175, no. 12, pp. 8409-8414, 2005.

[106] C. L. Keech, T. P. Gordon, and J. McCluskey, "The immune response to $52-\mathrm{kDa}$ Ro and $60-\mathrm{kDa}$ Ro is Linked in Experimental Autoimmunity," Journal of Immunology, vol. 157, no. 8, pp. 3694-3699, 1996.

[107] B. T. Kurien, S. Asfa, C. Li, Y. Dorri, R. Jonsson, and R. H. Scofield, "Induction of oral tolerance in experimental Sjögren's syndrome autoimmunity," Scandinavian Journal of Immunology, vol. 61, no. 5, pp. 418-425, 2005.

[108] P. Reynolds, T. P. Gordon, A. W. Purcell, D. C. Jackson, and J. McCluskey, "Hierarchical self-tolerance to $\mathrm{T}$ cell determinants within the ubiquitous nuclear self-antigen La (SS-B) permits induction of systemic autoimmunity in normal mice," Journal of Experimental Medicine, vol. 184, no. 5, pp. 1857-1870, 1996.

[109] F. Topfer, T. Gordon, and J. Mccluskey, "Intra- and intermolecular spreading of autoimmunity involving the nuclear self-antigens La (SS-B) and Ro (SS-A)," Proceedings of the National Academy of Sciences of the United States of America, vol. 92, no. 3, pp. 875-879, 1995.

[110] C. E. Tseng, E. K. L. Chan, E. Miranda, M. Gross, F. Di Donato, and J. P. Buyon, "The 52-kd protein as a target of intermolecular spreading of the immune response to components of the SS-A/Ro-SS-B/La complex," Arthritis and Rheumatism, vol. 40, no. 5, pp. 936-944, 1997.

[111] R. H. Scofield, K. M. Kaufman, U. Baber, J. A. James, J. B. Harley, and B. T. Kurien, "Immunization of mice with human 60-kd Ro peptides results in epitope spreading if the peptides are highly homologous between human and mouse," Arthritis and Rheumatism, vol. 42, no. 5, pp. 10171024, 1999.

[112] L. A. Lagenaur, W. C. Manning, J. Vieira, C. L. Martens, and E. S. Mocarski, "Structure and function of the murine cytomegalovirus sgg1 gene: a determinant of viral growth in salivary gland acinar cells," Journal of Virology, vol. 68, no. 12, pp. 7717-7727, 1994.

[113] H. A. McCordock, and M. G. Smith, "The visceral lesions produced in mice by the salivary gland virus of mice," Journal of Experimental Medicine, vol. 63, no. 3, pp. 303-310, 1936.

[114] C. A. Mims and J. Gould, "Infection of salivary glands, kidneys, adrenals, ovaries and epithelia by murine cytomegalovirus," Journal of Medical Microbiology, vol. 12, no. 1, pp. 113-122, 1979.

[115] V. J. Cavanaugh, Y. Deng, M. P. Birkenbach, J. S. Slater, and A. E. Campbell, "Vigorous innate and virus-specific cytotoxic T-lymphocyte responses to murine cytomegalovirus in the submaxillary salivary gland," Journal of Virology, vol. 77, no. 3, pp. 1703-1717, 2003.

[116] D. Henson and A. J. Strano, "Mouse cytomegalovirus. Necrosis of infected and morphologically normal submaxillary gland acinar cells during termination of chronic infection," American Journal of Pathology, vol. 68, no. 1, pp. 183-202, 1972.

[117] M. Fleck, E. R. Kern, T. Zhou, B. Lang, and J. D. Mountz, "Murine cytomegalovirus induces a Sjogren's syndrome-like disease in C57B1/6-lpr/lpr mice," Arthritis and Rheumatism, vol. 41, no. 12, pp. 2175-2184, 1998.

[118] Y. Ohyama, V. A. Carroll, U. Deshmukh, F. Gaskin, M. G. Brown, and S. M. Fu, "Severe focal sialadenitis and dacryoadenitis in NZM2328 mice induced by MCMV: a novel model for human Sjögren's syndrome," Journal of Immunology, vol. 177, no. 10, pp. 7391-7397, 2006.
[119] K. Fujiwara, N. Sakaguchi, and T. Watanabe, "Sialoadenitis in experimental graft-versus-host disease. An animal model of Sjogren's syndrome," Laboratory Investigation, vol. 65, no. 6, pp. 710-718, 1991.

[120] I. Sorensen, A. P. Ussing, J. U. Prause, J. Blom, S. Larsen, and J. V. Sparck, "Histopathological changes in exocrine glands of murine transplantation chimeras. I: the development of Sjogren's syndrome-like changes secondary to GVH induced lupus syndrome," Autoimmunity, vol. 11, no. 4, pp. 261-271, 1992.

[121] A. P. Ussing, J. U. Prause, I. Sorensen, S. Larsen, and J. V. Sparcke, "Histopathological changes in exocrine glands of murine transplantation chimeras. II: sjogren's syndrome-like exocrinopathy in mice without lupus nephritis. A model of primary Sjogren's syndrome," Autoimmunity, vol. 11, no. 4, pp. 273-280, 1992.

[122] A. P. Ussing, H. J. J. Baelde, S. Olesen Larsen, P. Naeser, J. U. Prause, and J. A. Bruijn, "Haematopathology of 'Sjogrenmice': histopathological changes in spleens after semiallogeneic cell transfer," Scandinavian Journal of Immunology, vol. 49, no. 6, pp. 641-648, 1999.

[123] S. Punekar, S. Zak, V. G. Kalter et al., "Thrombospondin 1 and its mimetic peptide ABT-510 decrease angiogenesis and inflammation in a murine model of inflammatory bowel disease," Pathobiology, vol. 75, no. 1, pp. 9-21, 2008. 


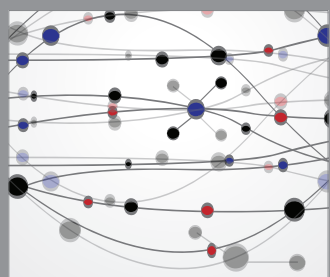

The Scientific World Journal
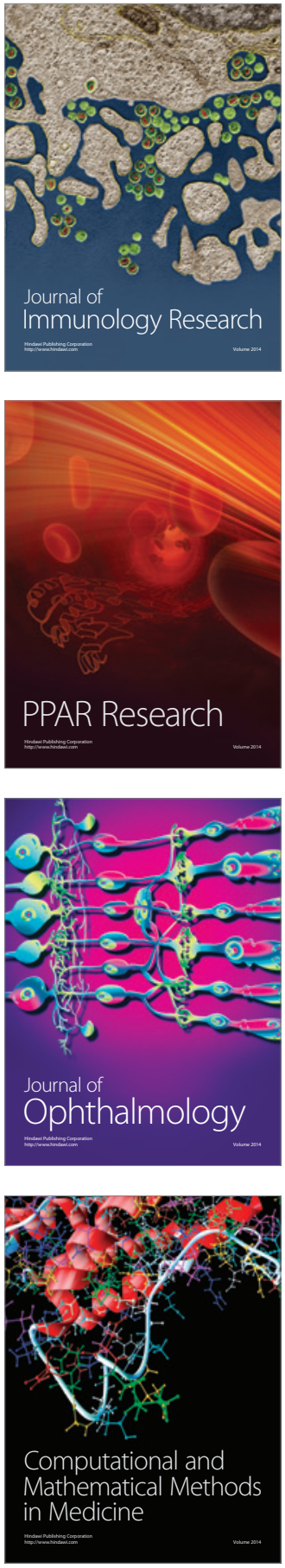

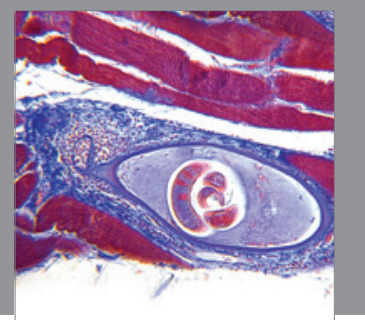

Gastroenterology

Research and Practice
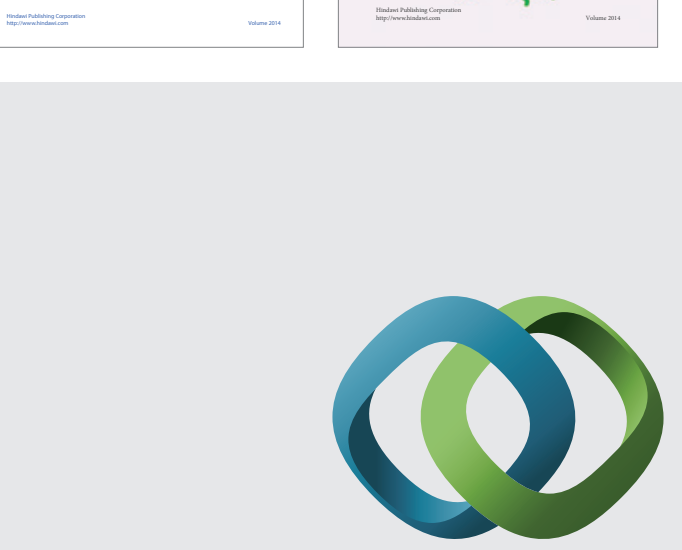

\section{Hindawi}

Submit your manuscripts at

http://www.hindawi.com
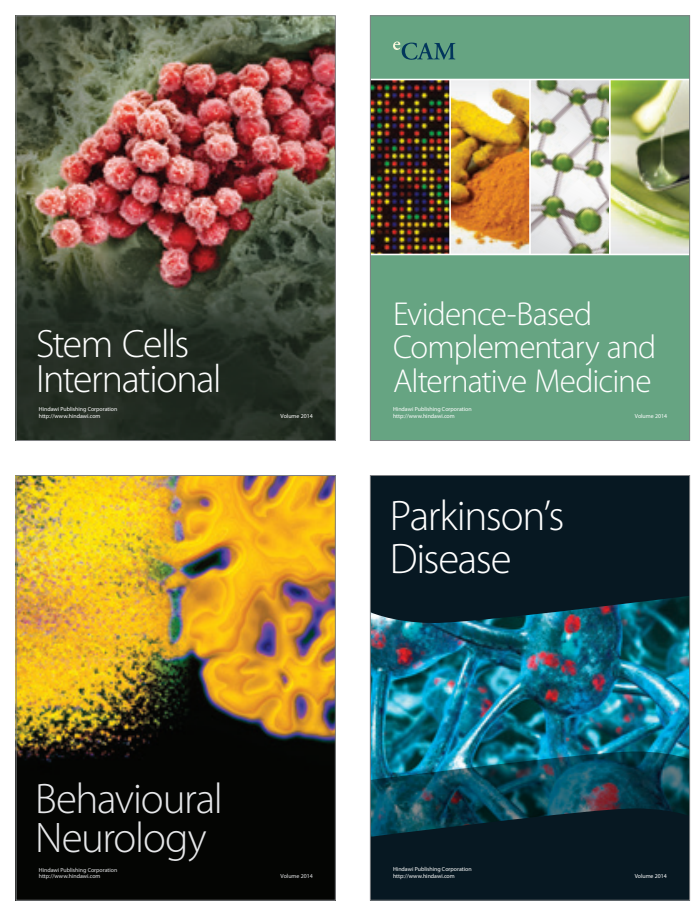

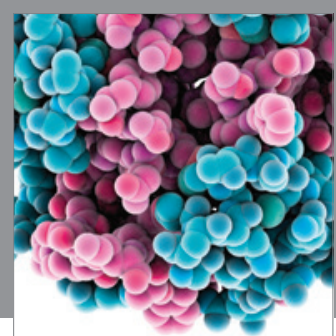

Journal of
Diabetes Research

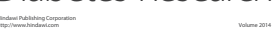

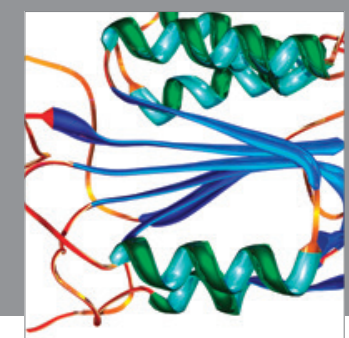

Disease Markers
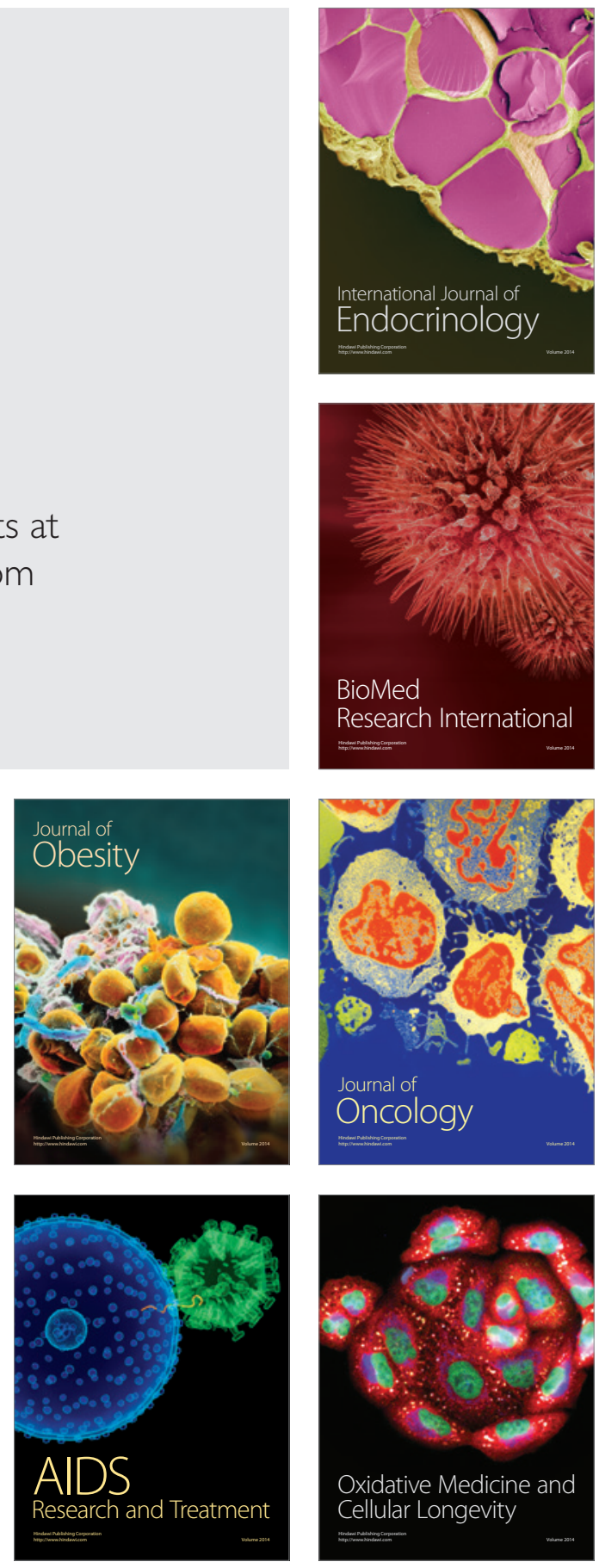